\title{
Comparative evaluation of cephalometric and occlusal characteristics between the Long Face pattern and Pattern I
}

\author{
Elisa Gurgel Simas de Oliveira', Célia Regina Maio Pinzan-Vercelino²
}

Objective: To compare the cephalometric and intraoral characteristics between Long Face pattern and Pattern I patients, besides evaluating associations between subjective facial patterns, cephalometric facial patterns and the intraoral characteristics. Methods: Through evaluation of frontal and right side extraoral photographs, three previously calibrated and experienced examiners selected 30 Long Face patients (Group 1) and 30 Pattern I patients (Group 2), aged between 9 and 19 years, of both genders. The cephalometric characteristics were assessed by the following variables: SN.GoGn, NS.Gn, AIFH, SNA, SNB, ANB, 1.1. 1.NA,1-NA, 1.NB, 1-NB, NA.Po, nasolabial angle and H-Nose. Clinical evaluations were also performed to determine the presence of posterior crossbite, anterior open bite and type of Angle's malocclusion. The cephalometric data were compared by independent $t$ test. The chi-square test was used to evaluate the association between qualitative variables. Results: Significant differences were observed between groups regarding the variables SN.GoGn, NS.Gn, AIFH, ANB, NA.Pog, 1-NA, 1.NB and 1-NB, with an increase of these measures in Group 1. There were also significant differences between groups on variable 1. 1 , being lower in Group 1 than in Group 2. Conclusions: The Long Face was associated to Angle Class II malocclusion, to the presence of posterior crossbite and to anterior open bite. The Long Face subjective facial pattern was associated to dolichofacial cephalometric pattern.

Keywords: Cephalometry. Orthodontics. Diagnosis.

Objetivo: comparar características cefalométricas e intrabucais entre pacientes Padrão Face Longa e Padrão I, além de avaliar as associações entre os padrões faciais subjetivos, os padrões faciais cefalométricos e as características intrabucais. Métodos: por meio da avaliação das fotografias extrabucais frontal e lateral direita, três examinadores experientes e previamente calibrados selecionaram 30 pacientes Padrão Face Longa (grupo 1) e 30 pacientes Padrão I (grupo 2), com idades entre 9 e 19 anos, de ambos os sexos. As características cefalométricas foram avaliadas por meio das seguintes variáveis: SN.GoGn, NS.Gn, AFAI, SNA, SNB, ANB, 1.1. 1.NA, 1-NA, 1.NB, 1-NB, NA.Pog, ângulo nasolabial e H-Nariz. Também foram realizadas avaliações clínicas para determinar a presença de mordida cruzada posterior, mordida aberta anterior e o tipo de má oclusão segundo Angle. Os dados cefalométricos obtidos foram comparados pelo teste $t$ independente. Utilizou-se o teste $\chi^{2}$ para avaliar a associação entre as variáveis qualitativas. Resultados: foram observadas diferenças estatisticamente significativas entre os grupos em relação às variáveis cefalométricas SN.GoGn, NS.Gn, AFAI, ANB, NA.Pog, 1-NA, 1.NB e 1-NB, com um aumento dessas medidas para o grupo 1. Ainda houve diferença significativa entre os grupos na variável $1 . \overline{1}$, sendo menor no grupo 1 do que no grupo 2 . Conclusões: o padrão face longa apresentou-se associado à má oclusão de Classe II de Angle, à presença de mordida cruzada posterior e à mordida aberta anterior. O padrão facial subjetivo face longa apresentou-se associado ao padrão facial cefalométrico dolicofacial. Palavras-chave: Circunferência craniana. Ortodontia. Diagnóstico.

» The authors report no commercial, proprietary or financial interest in the products or companies described in this article.

${ }^{1} \mathrm{MSc}$ in Orthodontics, UniCEUMA

${ }^{2}$ Professor, Post-Graduation Program - MSc in Orthodontics -UniCEUMA
How to cite this article: Oliveira EGS, Pinzan-Vercelino CRM. Comparative evaluation of cephalometric and occlusal characteristics between the Long Face Pattern and Pattern I. Dental Press J Orthod. 2013 May-June;18(3):86-93.

Submitted: January 22, 2010 - Revised and accepted: December 29, 2010

» The patients displayed in this article previously approved the use of their facial and intraoral photographs.

Contact address: Elisa Gurgel Simas de Oliveira Av. Dom Luís, 906/405 - Bairro Meireles - Brazil CEP: 60.160-230 - Fortaleza/CE - E-mail: elisasimas@hotmail.com 


\section{INTRODUCTION}

The long face is a deformity with skeletal implication and with unfavorable esthetics, ${ }^{8,10}$ that can be observed in the three sagittal dental relations, being however, more associated to Class II sagittal discrepancies. ${ }^{7,10}$

The children, teenagers and adults that present this excessive vertical facial growth, have a peculiar characteristic, described in literature as "Long Face syndrome", ${ }^{4,30}$ hyperdivergent facial type ${ }^{16,24}$ and, recently, as Long Face pattern..$^{7-11}$

The diagnosis of Long Face pattern is based in evaluations of the face morphology and cephalometry. The facial analysis allows to verify several characteristics common to these individuals such as: Absence of passive lip seal and contraction of mentalis muscles during labial closure, ${ }^{1}$ besides a great exposure of upper incisors when lips are resting and great gingival exposure during smile, ${ }^{1,4,30}$ the nose is generally long, with narrowing of the alar bases and the lower third of the face is increased, resulting in retrognathia appearance of the mandible. ${ }^{1,26,30}$

The cephalometry constitutes a necessary instrument to define, locate and quantify the skeletal disharmony present in patients with Long Face pattern, which can be associated to a horizontal growth of the condyle $\mathrm{e}^{6,26}$ and/or to an excessive posterior growth of the maxilla. ${ }^{15,30}$

Regarding the cephalometric characteristics, it is observed an increase on the total anterior height of the face and on the anterior and inferior facial height. ${ }^{15,17}$ The anterior and superior facial height is generally normal, ${ }^{1,430}$ but the proportion between medium and lower third is reduced. ${ }^{3}$ The angle of the mandibular plane is increased, ${ }^{4,8,11,15,28,29}$ as well as the gonial angle. ${ }^{8,11}$ It is observed a mandibular retropositioning in relation to the skull base. ${ }^{1,11}$ The maxilla, however, is well positioned in relation to the skull base. ${ }^{1,15}$

Lately, it is observed in literature ${ }^{13,21}$ that the cephalometric means, used in several cephalometric tracings, cannot be generically applied for diagnosis and treatment. Several researchers ${ }^{5,20,23}$ concluded that most cephalometric standards varies significantly, when compared to several facial patterns. Before this, a more individualized interpretation of the cephalometry must become a rule, or rather, an association between the cephalometric analysis and the facial analysis must be standard for diagnosis, plan- ning of treatment and orthodontic treatment. Therefore, the final decision of a planning must be taken based in cephalometric and facial findings. This way, this work had as objective to perform a comparative study of cephalometric and intraoral characteristics between Long Face patients and Pattern I, diagnosed by the subjective facial analysis, besides evaluating the associations between subjective facial patterns and cephalometric facial patterns.

\section{MATERIAL AND METHODS \\ Material}

The sample was selected according to the following criteria of inclusion:

"Caucasians;

" Long Face pattern or Pattern I;

"Full orthodontic records;

"Ages between 9 and 19 years;

"No previous orthodontic treatment.

\section{Methods}

\section{Orthodontic records}

Extraoral, frontal and right side photographs from the orthodontic records belonging to patients registered for orthodontic treatment on the Specialization Course in Orthodontics, of the Odontology Academy of Ceará were used. The sample was selected by three experienced and previously calibrated examinators, in distinct moments and each one individually, to avoid that the evaluation of one examinator interfered on the others. Only the patients who had diagnostic concordance were selected.

All photographs were performed by the same radiology center (Prof. Perboyre Castelo), presenting a pattern. The patients during the photographs were in natural position of the head $(\mathrm{NPH}):^{22}$ standing,with the feet $10 \mathrm{~cm}$ apart from each other, lips at rest, looking to an oval mirror located 1 meter before the patient and instructed to observe their own eyes reflection, keeping the pupils on the eye center.

The patients classified with Long Face pattern, ${ }^{7-11}$ were on the frontal and right side photograph with excessive exposure of the resting teeth and gingiva when smiling, lower third of the face increased in relation to the medium third, difficulty of lip seal, resting upper lip with short appearance, everted lower lip, retruded mandible and short chin-neck line (Figs 1 and 2). 

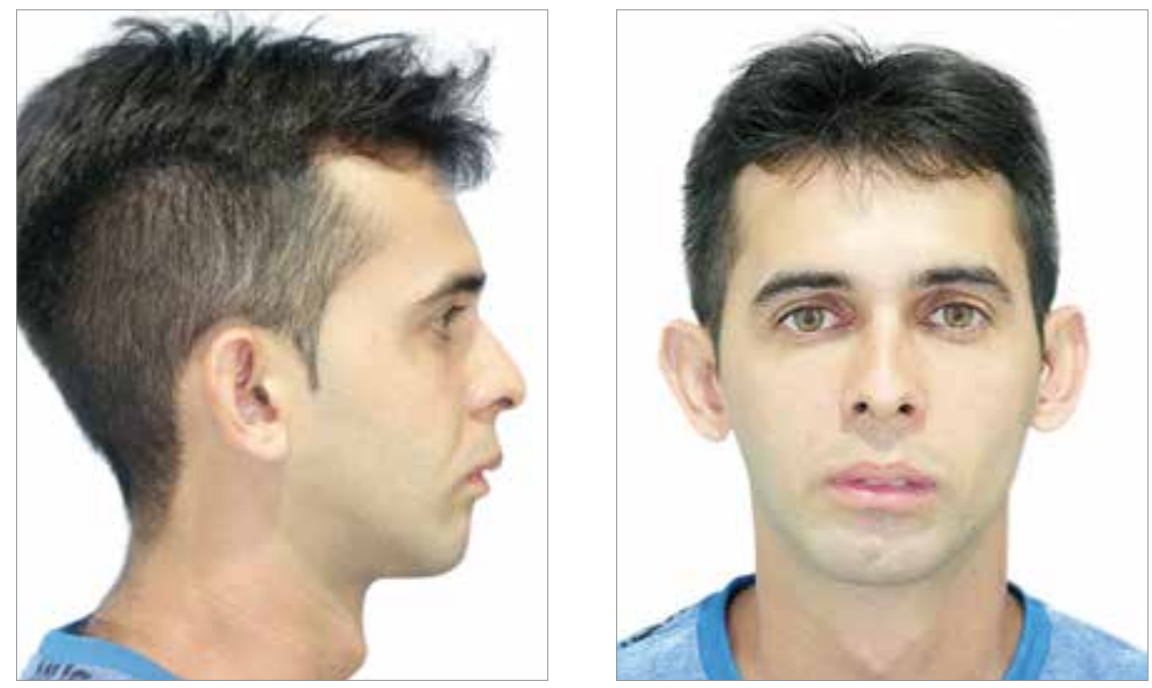

Figure 1 and 2 - Frontal and right side photograph of long face pattern patient.

The Pattern I patients ${ }^{7-11,13}$ were identified by the facial normality and characterized by balanced vertical and skeletal sagittal relations on the front and profile evaluations. In frontal photograph they had apparent symmetry, proportion between the facial thirds, proportional volume of the lips vermilion and passive lip seal (Fig 3). On the evaluation of the right side photograph, Pattern I patients had mild facial convexity, expressive chin-neck line and parallel to Camper plane, and esthetically pleasant mentolabial sulcus, built with equal participation of the mentum and lower lip (Fig 4).

The patient's full name, gender and date of birth were obtained also from the orthodontic records. The date of birth allowed the accurate calculus of initial ages of the patients.

All patients that agreed to participate in the research filled out a form with their data, as well as signed a free informed term of consent (FITC), approved by the ethics committee in research (CER) of the University Center of Maranhão (UNICEUMA), protocol number $00469 / 08$, according to standards of the resolution CNS 196/96.

\section{Cephalometry}

After evaluation of the photographs from orthodontic records for selection of the sample, the facial pattern was evaluated through cephalometry with variables that determined the facial growth pattern: SN.GoGn, NS.Gn (Axis Y) and AIFH (anterior inferior facial height).
Besides these variables, other measurements were performed of the skeletal components (SNA, SNB and ANB), dentoalveolar components (1.1. 1.NA, 1-NA, 1.NB, 1-NB) and bone and tissue profiles (NAPog, nasolabial angle, H-Nose).

The radiographs were performed by the digital panoramic x-ray device (Orthopantomograph OP100-D, Instrumentarium, Palodex group, Tuusula, Finland, 2006). This digital device used a sensor that sent the images captured in the radiographic take to the computer screen. These images were saved in CD and printed in films by laser printer model Dryview 8150 . The digital radiographic images were inserted on the program Cef X (CDT Software, Dourados, Mato Grosso, Brazil, version 2.1.24, 1995) and the reference points, lines and planes were demarcated.

The cephalometric facial pattern was determined when the patient showed at least two measures alterated. It was considered: Dolichofacial the patient that showed SN.GoGn with values higher than 34 degrees, ${ }^{19}$ NS.Gn (Axis Y) with values higher than 69.9 degrees $^{19}$ and AIFH with values higher than $71 \mathrm{~mm} ;{ }^{27}$ mesofacial the patient that showed SN.GoGn with values within 30 and 34 degrees, ${ }^{19}$ NS.Gn with values within 63.5 and 69.5 degrees $^{19}$ and AIFH with values within 63 and $71 \mathrm{~mm}^{27}$ and brachyfacial the patient that showed SN.GoGn with values lower than 30 degrees, ${ }^{19}$ NS.Gn with values lower than 63.5 degrees, ${ }^{19}$ and AIFH with values lower than $63 \mathrm{~mm} \cdot{ }^{27}$ 

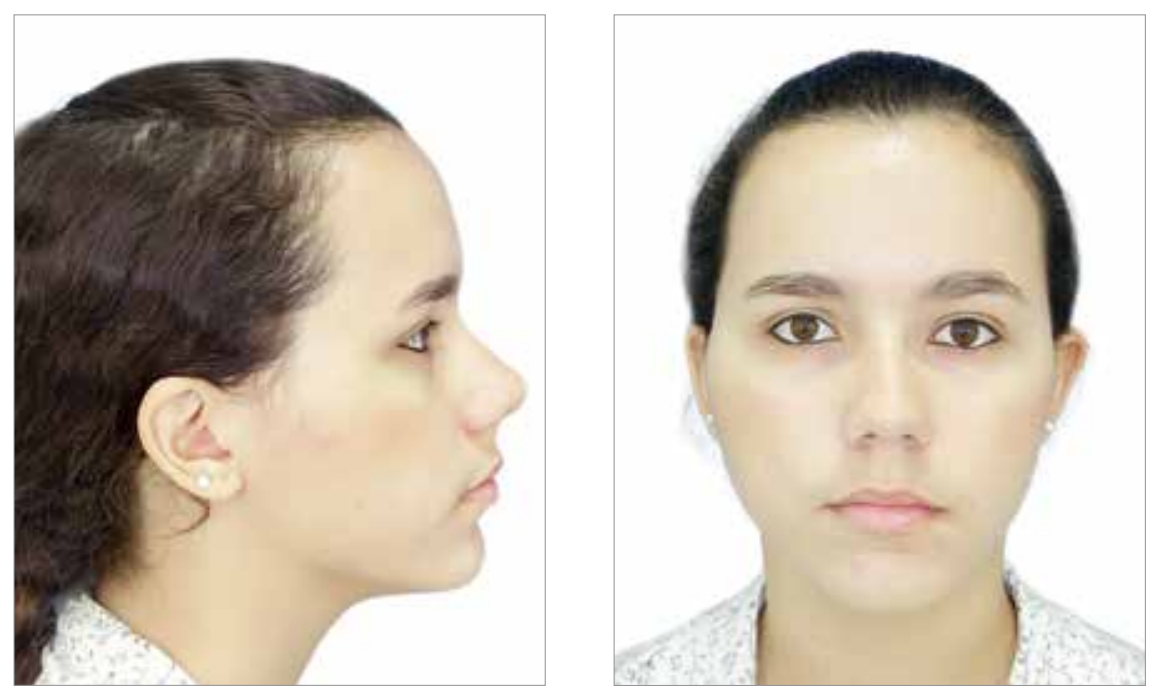

Figure 3 and 4 - Right side and frontal photograph of Pattern I patient.

\section{Clinical assessment}

It was filled out a clinical form for each patient containing data obtained from orthodontic records and observations such as: Initial age, presence of open bite and/ or crossbite and classification of Angle's malocclusion.

The patients classified with presence of posterior crossbite, were those with abnormal buccolingual relation between superior and inferior teeth, of at least three teeth, when the dental arches were in centric relation, being uni or bilateral ${ }^{25}$ and with presence of anterior open bite when showed a negative overbite between the edges of anterior, superior and inferior teeth, with measurement larger than $1 \mathrm{~mm}$, obtained in millimetric ruler. ${ }^{25}$

On the investigation of the dental relation, it was observed a sagittal relation between the upper and lower permanent first molars. ${ }^{2}$ The patients were classified as Class I, when presented a molar relation with the upper permanent first molar's mesiobuccal cusp occluding the lower permanent first molar's mesiobuccal sulcus, ${ }^{2}$ as Class II when presented the lower permanent first molar positioned distally in relation to the upper permanent first molar and as Class III when presented the lower permanent first molars situated mesially to the upper permanent first molars. ${ }^{2}$

\section{Statistical analysis}

Method error

To determine the reliability of the obtained cephalometric results, after 15 days, it was randomly selected a group of $20 \%$ of the radiographs, that were digitalized again and had their points demarcated by the same researcher. It was applied the dependent Student's t test in order to assess the systematic error. ${ }^{18}$ For evaluation of the random error it was used the Dahlberg's formula. ${ }^{12}$

\section{Statistical test}

It was used the descriptive statistics (mean and standard deviation) for initial age and all cephalometric measures used.

The independent $t$ test was applied to verify the compatibility between the initial ages of studied groups and to compare the cephalometric variables between groups.

It was applied the Chi-square test to evaluate the compatibility of groups regarding the proportion between genders, to verify the association between subjective facial pattern and cephalometric facial pattern and to evaluate the association of Long Face pattern and intraoral characteristics (posterior crossbite, anterior open bite and Angle's malocclusion).

Besides these tests, it was determined the prevalences of cephalometric facial patterns, posterior crossbite, anterior open bite and the type of Angle's malocclusion in relation to subjective facial pattern. Results with $\mathrm{p}<0,05$ were considered statistically significant. Tests were applied through BioEstat 5.0 (AYRES, Sociedade Civil Mamirauá, MCT-CNPq, Belém, PA, Brazil, 2005). 


\section{RESULTS}

The sample consisted of photographs and teleradiographs of 60 patients, divided in two groups according to facial pattern (Table 1).

Regarding the method error, for the cephalometric variables it was not detected any random error and only one systematic error. For the variable NS.Gn, it was found, on the first measurement, a mean value of 72.62 degrees, and for the second measurement a mean value of 73.97 degrees. Considering that it occurred only one systematic error (7.15\%) with variation of 1.35 degrees between the measurements, and none random error, the obtained results can be considered reliable.

The groups were compatible in relation to age and distribution of genders (Tables 2 and 3 ).

Regarding cephalometric variables, the studied groups presented statistically significant differences in: NS.GoGn, NS.Gn, AIFH, ANB, 1.1, 1-NA, 1.NB, 1-NB, NA.Pog (Table 2).

The Long Face pattern was associated to dolichofacial cephalometric facial pattern, and the Pattern I was associated to mesofacial cephalometric facial pattern (Table 3).

The Long Face pattern patients were associated to posterior crossbite, anterior open bite and Angle Class II malocclusion (Table 3).

Among the Long Face pattern patients 93.3\% were dolichofacial patients, $43.3 \%$ with presence of posterior crossbite, $16.6 \%$ with presence of anterior open bite and 60\% with Angle Class II malocclusion (Table 4).

Now, on the group of Pattern I patients $83.3 \%$ were mesofacial patients, $13.3 \%$ with presence of posterior

Table 1 - Classification of the sample according to age and gender

\begin{tabular}{lcc}
\hline Variables & $\begin{array}{c}\text { GROUP } \mathbf{1}(\boldsymbol{n}=\mathbf{3 0}) \\
\text { LONG FACE }\end{array}$ & $\begin{array}{c}\text { GROUP } 2(\boldsymbol{n}=\mathbf{3 0}) \\
\text { PATTERN I }\end{array}$ \\
\hline Age & $13.43 \pm 2.95$ & $12.83 \pm 3.02$ \\
\hline Mean \pm SD & 9 & 9 \\
\hline Maximum age & 18 & 19 \\
\hline Minimum age & & 13 \\
Gender & 13 & 17 \\
\hline Male & 17 & \\
\hline Female &
\end{tabular}

Table 2 - Comparative analysis of cephalometric variables and age between groups, according to independent $t$ test

\begin{tabular}{|c|c|c|c|}
\hline \multirow{3}{*}{ Variables } & GROUP $1(n=30)$ & GROUP $2(n=30)$ & \multirow{3}{*}{ p } \\
\hline & LONG FACE & PATTERN I & \\
\hline & Mean \pm SD & Mean \pm SD & \\
\hline \multicolumn{4}{|l|}{ Skeletal components } \\
\hline SNA (degrees) & $82.86 \pm 4.29$ & $82.59 \pm 4.00$ & 0.802 \\
\hline SNB (degrees) & $78.00 \pm 4.49$ & $79.06 \pm 3.92$ & 0.333 \\
\hline ANB (degrees) & $4.85 \pm 2.22$ & $3.57 \pm 2.01$ & $0.022^{*}$ \\
\hline \multicolumn{4}{|l|}{ Growth pattern } \\
\hline SN.GoGn (degrees) & $41.80 \pm 6.78$ & $34.37 \pm 6.77$ & $0.000 *$ \\
\hline NS.Gn (degrees) & $70.90 \pm 4.64$ & $67.76 \pm 4.03$ & $0.006^{*}$ \\
\hline AIFH (mm) & $77.49 \pm 8.88$ & $68.64 \pm 6.23$ & $0.000 *$ \\
\hline \multicolumn{4}{|c|}{ Dentoalveolar components } \\
\hline $1 \overline{1}$ (degrees) & $117.11 \pm 14.56$ & $124.79 \pm 10.58$ & $0.022^{*}$ \\
\hline 1.NA (degrees) & $26.27 \pm 10.24$ & $23.02 \pm 7.26$ & 0.161 \\
\hline 1-NA (mm) & $6.27 \pm 3.91$ & $4.45 \pm 2.33$ & $0.033^{*}$ \\
\hline 1.NB (degrees) & $31.80 \pm 7.39$ & $27.80 \pm 6.13$ & $0.026^{*}$ \\
\hline 1-NB (mm) & $8.32 \pm 2.87$ & $5.78 \pm 2.42$ & $0.000^{*}$ \\
\hline \multicolumn{4}{|c|}{ Osseous profile $x$ tissue profile } \\
\hline NA.Pog (degrees) & $9.14 \pm 4.91$ & $6.07 \pm 4.69$ & $0.016^{*}$ \\
\hline ANL (degrees) & $98.84 \pm 13.54$ & $101.24 \pm 9.88$ & 0.435 \\
\hline H-Nose $(\mathrm{mm})$ & $2.18 \pm 4.62$ & $2.99 \pm 3.19$ & 0.434 \\
\hline \multicolumn{4}{|c|}{ Compatibility between ages } \\
\hline Age & $13.43 \pm 2.95$ & $12.83 \pm 3.02$ & 0.444 \\
\hline
\end{tabular}

*Statistically significant $(p<0.05)$.

Table 3 - Analysis of the compatibility of genders, facial pattern, cephalometric facial pattern, posterior crossbite, anterior open bite and classification of the Angle's malocclusions between the groups, according to Chi-square test.

\begin{tabular}{|c|c|c|c|c|c|}
\hline Variables & $\begin{array}{c}\text { GROUP } 1 \\
(n=30) \\
\text { LONG FACE }\end{array}$ & $\begin{array}{c}\text { GROUP } 2 \\
(n=30) \\
\text { PATTERN I }\end{array}$ & Total & $\chi^{2}$ & $\mathbf{P}$ \\
\hline \multicolumn{6}{|l|}{ Gender } \\
\hline Female & 17 & 17 & 34 & 0.00 & \multirow{2}{*}{1.00} \\
\hline Male & 13 & 13 & 26 & & \\
\hline \multicolumn{6}{|c|}{ Cephalometric facial pattern } \\
\hline Brachyfacial & 0 & 3 & 3 & 45.126 & \multirow{3}{*}{$0.000^{*}$} \\
\hline Dolichofacial & 28 & 2 & 30 & & \\
\hline Mesofacial & 2 & 25 & 27 & & \\
\hline \multicolumn{6}{|c|}{ Posterior crossbite } \\
\hline Absence & 17 & 26 & 43 & 6.65 & \multirow{2}{*}{$0.010^{*}$} \\
\hline Presence & 13 & 4 & 17 & & \\
\hline \multicolumn{5}{|c|}{ Anterior open bite } & \multirow{3}{*}{$0.020^{*}$} \\
\hline Absence & 25 & 30 & 55 & 5.45 & \\
\hline Presence & 5 & 0 & 5 & & \\
\hline \multicolumn{6}{|c|}{ Angle classification } \\
\hline Class I & 11 & 21 & 32 & 7.125 & \multirow{3}{*}{$0.028^{*}$} \\
\hline Class II & 18 & 9 & 27 & & \\
\hline Class III & 1 & 0 & 1 & & \\
\hline
\end{tabular}


Table 4 - Prevalence of cephalometric facial patterns, posterior crossbite, anterior open bite and type of Angle's malocclusion on the different groups.

\begin{tabular}{|ccc}
\hline Variables & $\begin{array}{c}\text { GROUP 1 } \\
(\mathbf{n}=30) \\
\text { LONG FACE }\end{array}$ & $\begin{array}{c}\text { CROUP 2 } \\
(\mathbf{n}=30) \\
\text { PATTERN I }\end{array}$ \\
\hline $\begin{array}{c}\text { Cephalometric facial pattern } \\
\text { Brachyfacial }\end{array}$ & $0 \%$ & $10 \%$ \\
\hline Dolichofacial & $93.3 \%$ & $6.6 \%$ \\
\hline Mesofacial & $6.6 \%$ & $83.3 \%$ \\
\hline Posterior crossbite & & \\
\hline Absence & $56.6 \%$ & $86.6 \%$ \\
\hline Presence & $43.3 \%$ & $13.3 \%$ \\
\hline Anterior open bite & & $100 \%$ \\
\hline Absence & $83.3 \%$ & $0 \%$ \\
\hline Presence & $16.6 \%$ & \\
\hline Angle classification & & $70 \%$ \\
\hline Class I & $36.6 \%$ & $30 \%$ \\
\hline Class II & $60 \%$ & $0 \%$ \\
\hline Class III & $3.3 \%$ & \\
\hline
\end{tabular}

crossbite, 70\% with Angle Class I maloccusion and 30\% with Angle Class II malocclusion. However, no Pattern I patient presented anterior open bite (Table 4).

\section{DISCUSSION}

The subjective facial analysis represents an important tool of orthodontic diagnosis, ${ }^{13}$ that can be easily used for identification of Long Face pattern patients. These patients generally present several occlusal problems that may be associated to this facial growth pattern as: posterior crossbite, anterior open bite and Class II malocclusion. Many times, when the problem of vertical growth is identified through the face, the problem is also cephalometrically confirmed, however, when the problem is diagnosed cephalometrically first, it is not necessarily confirmed on the face, ie, the facial analysis allows a more accurate diagnosis of the Long Face pattern.

On the cephalometric assessment, the groups presented significative differences in relation to the following variables: SN.GoGn, NS.Gn, AIFH, ANB, 1.1, 1-NA, 1.NB, 1-NB and NA.Pog. The Long Face pattern patients presented increase

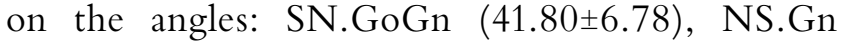
(70.90土4.64), indicating vertical growth pattern;
NA.Pog (9.14 \pm 4.91$)$, showing increase of convexity of the bone profile; ANB $(4.85 \pm 2.22)$, evidencing the increase on degree of sagittal discrepancy be-

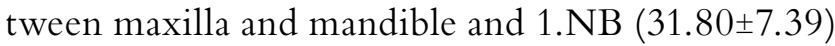
indicating vestibularization of lower incisors in relation to bone base. The linear measures 1-NA (26.27 \pm 10.24$), \quad 1-\mathrm{NB} \quad(8.32 \pm 2.87)$ and AIFH $(77.49 \pm 8.88)$ were increased; indicating protrusion of upper and lower incisors and increase of the lower third of the face. The measure 1.1, that also presented significative difference between groups, showed decreased value for Long Face pattern patients, factor indicative of maxillomandibular retrusion.

Cardoso et $\mathrm{al}^{11}$ also found significative differences in relation to the variables ANB, AIFH, SN.GoGn and NA.Pog when compared the cephalometric characteristics of Long Face pattern and of Pattern I. ${ }^{11}$ They observed that Long Face pattern individuals presented increase of the cephalometric measures located below the palatal plane. ${ }^{11}$

Capelozza Filho et $\mathrm{al}^{8}$ evaluating the cephalometric characteristics of Long Face pattern, did not observe significative differences in relation to sexual dimorphism and showed that male Long Face pattern patients, when compared to Pattern I patients, presented disparities in relation to magnitudes related to facial height, to growth pattern and to sagittal relation.

The assessment of maxillomandibular relation, based on value of angle ANB, was greater also in Long Face pattern individuals evaluated by Cardoso et $\mathrm{al}^{9}$ and Capelozza Filho et $\mathrm{al}^{,}{ }^{8}$ showing the tendency to Class II malocclusion that the carriers of this deformity present. The values for anterior and inferior facial height were higher for the Long Face pattern group with statistical significance, also observed in studies performed by Cardoso et $\mathrm{al}^{9}$ and Capelozza Filho et $a .^{8}$ This result was also expected, since the increase on anterior inferior facial height constitutes the essence of the studied disease, being frequently found in literature.

Regarding the mandibular plane (SNGoGn), the mean values of this angle for Long Face pattern individuals were close to the maximum values of Pattern I individuals. This implies on the necessity of association of several cephalometric characteristics for definition of the Long Face pattern. Values above 37 degrees for the angle of the mandibular plane were reported in litera- 
ture $4,14,15,16,20,28,29$ as parameter to define Long Face pattern individuals. Although the values found in the studies performed by Capelozza Filho et $\mathrm{al}^{8}$ and Cardoso et $\mathrm{al}^{9}$ overcome this value, they cannot be used separately. In fact, the disease consists in an imbalance between the vertical components, and, therefore, a single parameter must not be used; therefore in this study it was associated to the mandibular plane (SN.GoGn), the measurement of the $\mathrm{Y}$ axis of growth (Ns.Gn) and the measurement of the anterior and inferior facial height for determination of cephalometric facial pattern.

The mandibular retrusion was emphasized with the assessment of NAP angle which was significantly different between Long Face pattern and Pattern I groups also in the study by Cardoso et $a 1,{ }^{10}$ showing greater mandibular retrognathia and convexity of bone profile in Long Face pattern patients.

As for the cephalometric growth pattern, it was obtained $93,3 \%$ of dolichofacial patients on Group 1 (Long Face pattern) and $83.3 \%$ of mesofacial patients on Group 2 (Pattern I). The Chi-square test showed presence of association between the subjective facial pattern and the cephalometric facial pattern, which allows to conclude that the studied facial patterns, classified by the subjective analysis, are associated to cephalometric classification of the facial pattern, enabling the methodology used for identification of patients by subjective facial analysis, besides allowing the comparison between results from this study and other results from works in literature.

The patients on Group 1 presented a prevalence of $43.3 \%$ of posterior crossbite and the patients on Group 2 presented $13.3 \%$ of posterior crossbite. In relation to the Chi-square test it was observed an association between facial pattern and posterior crossbite. The prevalence of posterior crossbite in Long Face pattern patients is according to the observed in a study by Cardoso et $\mathrm{al}^{10}$ in which the authors showed a prevalence of $34.2 \%$ of this malocclusion.

Regarding the presence of anterior open bite, the patients on Group 1 presented a prevalence of $16.6 \%$, while on Group 2, no patients showed anterior open bite. In relation to the Chi-square test, it was observed an association between the Long Face pattern and the presence of anterior open bite.

About Angle's classification, the patients on Group 1 presented: 36.6\% Class I, 60\% Class II and 3.33\% Class III; now the patients on Group 2 presented: 70\% Class I and 30\% Class II. As result of the Chi-square test, it was found an association between the facial pattern and Angle's classification. Patients on Group 1 were associated to Class II malocclusion and patients on Group 2 were associated to Class I malocclusion. This result agrees with the study performed by Cardoso et a ${ }^{10}$ who found in Long Face pattern patients the following prevalences in relation to Angle malocclusions: 13.2\% Class I, 71\% Class II and 15.8\% Class III. Probably, the Long Face pattern is associated to Class II malocclusion for these patients present a clockwise mandibular rotation, which facilitate a Class II sagittal relation.

\section{CONCLUSIONS}

The Long Face pattern was associated to Angle Class II malocclusion, to presence of posterior crossbite and to anterior open bite. The subjective Long Face pattern was associated to dolichofacial cephalometric facial pattern. 


\section{REFERENCES}

1. Angelillo JC, Dolan EA. The surgical correction of vertical maxillary excess: long face syndrome. Ann Plast Surg. 1982;8(1):64-70.

2. Angle $\mathrm{EH}$. Classification of malocclusion. Dent Cosmos. $1899 ; 41(3): 248-64$

3. Bell WH. Correction of skeletal type of anterior open bite. J Oral Surg. 1971:29(10):706-14.

4. Bell WH, Creekmore TD, Alexander RG. Surgical correction of the long face syndrome. Am J Orthod. 1977:71(1):40-67.

5. Bhat M, Enlow DH. Facial variations related to head form type. Angle Orthod. 1985;55(4):269-80

6. Bjork A. Prediction of mandibular growth rotation. Am J Orthod 1969:55(6):585-99

7. Capelozza Filho L. Diagnóstico em Ortodontia. 1a ed. Maringá: Dental Press; 2004

8. Capelozza Filho L, Cardoso MA, An TL, Bertoz FA. Características cefalométricas do padrão face longa: considerando o dimorfismo sexual. Rev Dental Press Ortod Ortop Facial. 2007:12(2):49-60.

9. Capelozza Filho L, Cardoso MA, An TL, Lauris JRP. Proposta para classificação, segundo a severidade, dos indivíduos portadores de más oclusões do padrão face longa. Rev Dental Press Ortod Ortop Facial. 2007:12(4):124-58

10. Cardoso MA, Bertoz FA, Reis SAB, Capelozza Filho L. Estudo das características oclusais em portadores de padrão face longa com indicação de tratamento ortodôntico-cirúrgico. Rev Dental Press Ortod Ortop Facial. 2002;7(9):63-70

11. Cardoso MA, Bertoz FA, Capelozza Filho L, Reis SAB. Características cefalométricas do padrão face longa. Rev Dental Press Ortod Ortop Facial. 2005;10(2):29-43

12. Dahlberg G. Statistical methods for medical and biological students. New York: Interscience; 1940

13. Feres R, Vasconcelos MHF. Estudo comparativo entre a análise facial subjetiva e a análise cefalométrica de tecidos moles no diagnóstico ortodôntico. Rev Dental Press Ortod Ortop Facial. 2009;14(2):81-9.

14. Fields HW, Proffit WR, Nixon WL, Phillips C, Stanek E. Facial pattern differences in long-faced children and adults. Am J Orthod. 1984:85(3):217-23
15. Fish LC, Wolford LM, Epker BN. Surgical orthodontic correction of maxillary excess. Am J Orthod. 1978;73(3):241-57.

16. Fitzpatrick BN. The long face and V.M.E. Aust Orthod J. 1984;8:82-9.

17. Frost DE, Fonseca RJ, Turvey TA, Hall DJ. Cephalometric diagnosis and surgical-orthodontic correction of apertognathia. Am J Orthod. 1980;78(6):657-69.

18. Houston WJ. Analysis of errors in orthodontics measurements. Am J Orthod. 1983;83(5):382-90.

19. Interlandi S. Ortodontia bases para iniciação. 5a ed. São Paulo: Artes Médicas; 2002.

20. Isaacson JR, Isaacson RJ, Speidel TM, Worms FW. Extreme variations in vertical face growth and associated variation in skeletal and dental relations. Angle Orthod. 1971;41(3):219-29.

21. Jacobson A. Planning for orthognatic surgery-art or science? Int J Adult Orthodon Orthognath Surg. 1990;5(4):217-24.

22. Lundström F, Lundström A. Natural head position as a basis for cephalometric analysis. Am J Orthod Dentofacial Orthop. 1992;101(3):244-7

23. Metzdorf DW. A cephalometric study of cranial, mandibular and lower incisor morphology in adult face. Angle Orthod. 1977;47(4):288-92

24. Moloney F, West RA, McNeill RW. Surgical correction of vertical maxillary excess: a re-evaluation. J Maxillofac Surg. 1982;10(2):84-91.

25. Moyers RE. Ortodontia. 4a ed. Rio de Janeiro: Guanabara Koogan; 1991

26. Nielsen IL. Vertical malocclusions: etiology, development, diagnosis and some aspects of treatment. Angle Orthod. 1991;61(4):247-60

27. Pinzan A, Pinzan-Vercelino CRM, Martins DR, Janson G, Henriques JFC, Freitas MR, et al. Crescimento maxilomandibular no sentido anteroposterior e na altura anterior. In: Atlas de Crescimento Craniofacial. 10 ed. São Paulo: Ed. Santos: 2006. p. 49-54.

28. Prittinen JR. Orthodontic diagnosis of long face syndrome. Gen Dent $1996 ; 44(4): 348-51$

29. Schendel SA, Carlotti AE Jr. Variation of vertical maxillary excess. J Oral Maxillofac Surg. 1985;43(8):590-6

30. Schendel SA, Eisenfeld J, Bell WH, Epker BN, Mishelevich DJ. The long face syndrome: vertical maxillary excess. Am J Orthod. 1976:70(4):398-408 